\title{
Inhibition of Scytalidium lignicolum Acid Protease B by 1-Diazo-3-phenyl-2-propanone
}

\author{
Daisuke Tsuru, Ryuji Kobayashi, Naoki Nakagawa \\ and Tadashi Yoshimoto
}

School of Pharmaceutical Sciences, Nagasaki University, Bunkyo-machi 1-14, Nagasaki 852, Japan

Received November 24, 1988

\begin{abstract}
The acid protease $\mathrm{B}$ from Scytalidium lignicolum, a pepstatin-insensitive acid protease, was modified with 1-diazo-3-phenyl-2-propanone (DPP) in the presence of cupric ions. About 1 mol of DPP per mol of enzyme was incorporated with a concomitant loss of the activity. The modified enzyme was digested with thermolysin and DPP-labeled peptides were separated. One peptide, called S1, was purified and its amino acid sequence was found to be Ala-Thr-Ser-Asp-Thr-Ser-Gly-Ser, which corresponds to the sequence of residue Nos. 95 102 of the enzyme. Alkali treatment of the modified peptide resulted in complete removal of the modifier, suggesting that DPP is esterlinked to Asp-98 of the enzyme. The amino acid sequence around Asp-98 of the enzyme was significantly homologous to those around the active site aspartic acid residues of penicillopepsin and porcine pepsin. These results suggest that Asp 98 is one of the active site amino acids of the enzyme.
\end{abstract}

Proteolytic enzymes active at acidic $\mathrm{pH}$, acid proteases, are now called aspartic proteases, since two aspartic acid residues have been shown to be involved in their catalytic reaction. ${ }^{1)}$ These enzymes are commonly inhibited by Streptomyces pepsin inhibitor (S-PI: acetyl-pepstatin), ${ }^{2)}$ diazoacetyl-DL-norleucine methylester (DAN $)^{3)}$ and 1,2-epoxy-3-( $p$ nitrophenoxy)propane (EPNP). ${ }^{4)}$ EPNP was reported to inhibit pepsin by ester-linking to Asp-32 and Asp-215, ${ }^{5}$ while DAN was inhibitory to pepsin in the presence of cupric ions through the reaction with Asp-215.3) Similar results were also reported in calf chymosin, ${ }^{6)}$ penicillopepsin, ${ }^{7)}$ and Rhizopuspep$\sin ^{8)}$

In 1972, Murao et al. ${ }^{9 y}$ found that three new types of acid proteases produced by a strain of Scytalidium lignicolum are insensitive to S-PI (Ac-pepstatin). These enzymes, designated A1, $\mathrm{A} 2$, and $\mathrm{B}$, were highly purified, and their enzymatic and physicochemical properties were characterized by Murao and Oda. ${ }^{10)}$ The former two enzymes were exceptionally insensitive to acid protease inhibitors mentioned above, while the last one (B enzyme) was inhibited by EPNP but insensitive to DAN and pepstatin. ${ }^{10,11)} \mathrm{We}^{12)}$ established the complete amino acid sequence of $S$. lignicolum acid protease $\mathrm{B}(\mathrm{SAB})$ and showed that there is only a little sequence homology between SAB and other acid proteases such as pepsin and penicillopepsin. This result and the discrepancy observed in the sensitivity to inhibitors seem to indicate that the active site structure of $\mathrm{SAB}$ is distinct from those of aspartic proteases hitherto reported.

Recently, we concluded that Glu- 53 of SAB is one of the active site amino acid residues because Glu-53 was modified with EPNP with the concomitant loss of the activity and the amino acid sequence of the EPNP-labeled peptide was highly homologous to those aound the active site Asp-215 of calf chymosin

Abbreviations: DPP, 1-diazo-3-phenyl-2-propanone; SAB, Scytalidium lignicolum acid protease B; S-PI, Streptomyces pepsin inhibitor (Ac-pepstatin); DAN, diazo-acetyl-DL-norleucine methylester; EPNP, 1,2-epoxy-3-( $p$-nitrophenoxy)propane; Rhizopuspepsin, acid protease from Rhizopus chinensis. 
and pepsin. ${ }^{13,14)}$

To investigate whether this Glu-53 is the sole acidic amino acid participating in the catalytic reaction of SAB, we synthesized several diazo-compounds and surveyed their inhibitory activity on $\mathrm{SAB}$ with and without the addition of cupric ions.

This paper deals with the inhibition of $\mathrm{SAB}$ with 1-diazo-3-phenyl-2-propanone (DPP). DPP was found to inhibit SAB and Rhizopuspepsin as well as porcine pepsin in the presence of cupric ions. Analyses of DPPlabeled peptides indicated that Asp-98 of SAB and Asp-215 of pepsin were modified by DPP.

\section{Materials and Methods}

Materials. Scytalidium lignicolum ATCC24568 was a generous gift from Professor S. Murao of the Kumamoto Institute of Technology. The strain was cultured aerobically in a medium containing $5 \%$ glucose, $1.5 \%$ meat extract, $0.2 \% \mathrm{KH}_{2} \mathrm{PO}_{4}, 0.05 \% \mathrm{MgSO}_{4} \cdot 7 \mathrm{H}_{2} \mathrm{O}$, and $0.1 \%$ yeast extract $(\mathrm{pH} 3.5)$ at $25^{\circ} \mathrm{C}$ for $90 \mathrm{hr}$ and the acid protease $\mathrm{B}(\mathrm{SAB})$ was purified from the culture filtrate by the method of Murao et al., ${ }^{9,10)}$ with a slight modification. Rhizopuspepsin was purifed as described previously. ${ }^{15}$ ) Porcine pepsin and thermolysin were purchased from Sigma Chemical Co., U.S.A. $N^{\alpha}$-Benzyloxycarbonyl-Lphenylalanyl diazomethane (ZPDM) was prepared by the method of Ong and Perlmann, ${ }^{16}$ yield: $41 \%$ mp: $84 \sim 85^{\circ} \mathrm{C}$. Elemental analysis, Calcd: C, $66.86 ; \mathrm{H}, 5.30 ; \mathrm{N}$, $13.00 \%$. Found: C, 66.99; H, 5.49; N, 11.88\%. 1-Diazo-3phenyl-2-propanone (DPP) was synthesized from phenylacetyl-chloride and diazomethane as described by Plattner and Heusser. ${ }^{17)}$ DPP was obtained as yellow crystals in a $90 \%$ yield, $\mathrm{mp} 46^{\circ} \mathrm{C}$. The IR spectra showed a diazo band at $2,110 \mathrm{~cm}^{-1}$ and thin-layer chromatography on silica gel plates (Merck, F254) in ethyl acetate gave a single spot with a $R f$ value of 0.73 , differing from that $(0.90)$ of the starting material, in ultraviolet irradiation. Elemental analysis, Calcd. for $\mathrm{C}, 67.49 ; \mathrm{H} ; 5.03 ; \mathrm{N}$, $17.49 \%$; Found: C, 67.68; H, 5.09; N, 16.58\%. All other chemicals were of reagent grade.

Assay of proteolytic activity and inhibition studies. The proteolytic activity was assayed by the method mentioned previously ${ }^{157}$ and inhibition studies were done as follows: enzymes $(0.025 \%)$ dissolved in $4 \mathrm{ml}$ of $0.1 \mathrm{M}$ sodium acetate buffer at appropriate $\mathrm{pHs}$ were incubated with $0.1 \mathrm{ml}$ of cupric acetate solution (a 50-fold molar excess over enzyme) at $14^{\circ} \mathrm{C}$ for $10 \mathrm{~min}$. Then, the reaction was started by the addition of ZPDM or DPP (the same ratio as cupric ion) dissolved in $0.1 \mathrm{ml}$ of methanol at $14^{\circ} \mathrm{C}$ under stirring in the dark. Samples of the reaction mixture were periodically withdrawn and the residual activities were assayed.

Preparation of modified enzymes. Pepsin $(4 \mathrm{mg})$ or SAB ( $8 \mathrm{mg}$ ) dissolved in $1 \mathrm{ml}$ of $0.1 \mathrm{M}$ sodium acetate buffer $(\mathrm{pH}$ 4.8) containing a 50 -fold molar excess of cupric acetate was incubated with DPP for $12 \mathrm{hr}$ at $14^{\circ} \mathrm{C}$ as above and the reaction mixture was dialyzed against three changes of $1 \mathrm{l}$ each of $10 \mathrm{~mm}$ acetic acid $\left(\mathrm{pH} \mathrm{3.4)}\right.$ ) at $4^{\circ} \mathrm{C}$ for every $4 \mathrm{hr}$ to remove excess reagents. The dialyzed solution containing the DPP-modified enzyme was gel filtered on a column $(7.5 \times 600 \mathrm{~mm})$ of Toso, TSK gel G3000SW equilibrated with $10 \mathrm{~mm}$ acetic acid at a flow rate of $0.7 \mathrm{ml} / \mathrm{min}$ to remove traces of contaminants. Elution of DPP-modified enzyme was monitored by following absorbances at 280 $\mathrm{nm}$ and $315 \mathrm{~nm}$.

The DPP incorporated into the enzyme was spectrophotometrically measured by using the molar extinction coefficients of DPP and enzymes. The values used for DPP were 5,610 at $315 \mathrm{~nm}$ and 230 at $280 \mathrm{~nm}$. The molar extinction coefficients of SAB and pepsin at $280 \mathrm{~nm}$ were assumed to be $34,700^{10)}$ and $46,000,{ }^{4)}$ respectively.

Proteolytic digestion of modified enzyme and the separation of peptides. DPP-modified SAB $(3.4 \mathrm{mg})$ was dialyzed against $3 \mathrm{I}$ of $0.1 \mathrm{M}$ sodium acetate buffer, $\mathrm{pH} 6.5$, containing $5 \mathrm{mM} \mathrm{CaCl}_{2}$ at $4^{\circ} \mathrm{C}$ and digested with thermolysin (molar ratio of enzyme/substrate: $1 / 100$ ) at $37^{\circ} \mathrm{C}$ for $2 \mathrm{hr}$ in a total volume of $0.8 \mathrm{ml}$. Samples $(100 \mu 1)$ of the digest were put on a reverse phase HPLC column $(4.6 \times$ $250 \mathrm{~mm}, 5 \mu \mathrm{m}$ ) of Toso, ODS $120 \mathrm{~T}$ equilibrated with $0.05 \%$ trifluoroacetic acid (TFA) at $25^{\circ} \mathrm{C}$ and eluted with an increasing gradient of acetonitrile containing $0.05 \%$ TFA $(0 \sim 15 \%$ for $30 \mathrm{~min}$ starting at $10 \mathrm{~min}$ after injection, and then $15 \sim 70 \%$ for $40 \mathrm{~min}$ ). The flow rate was $1.0 \mathrm{ml} /$ min and the elution of peptides was monitored by following absorbances at $214 \mathrm{~nm}$ and $315 \mathrm{~nm}$, respectively.

Removal of modifier from the labeled peptides. The DPPmodified peptides were incubated with $0.5 \mathrm{~N}$ hydroxylamine $(\mathrm{pH} 10.5)$ at $37^{\circ} \mathrm{C}$ for $24 \mathrm{hr}$ and the reaction mixtures were analyzed by HPLC. Elution profiles of peptides and modifier were spectrophotometrically monitored at $214 \mathrm{~nm}$ and $315 \mathrm{~nm}$.

Identification of amino acid sequence of the modified peptides. The amino acid sequences of DPP-labeled peptide fragments were identified by manual Edmann degradation by the method of Kobayashi and Tarr. ${ }^{18)}$

\section{Results}

Effects of DPP and ZPDM on activities of $S A B$, pepsin, and Rhizopuspepsin

Three acid proteases were incubated with DPP or ZPDM at $\mathrm{pH} 4.8$ in the presence or 
absence of cupric ions. The results are shown in Table I. DPP inhibited all of these acid proteases in the presence of $\mathrm{Cu}^{2+}$, while ZPDM was inhibitory only to Rhizopuspepsin and pepsin.

In Fig. 1, the effects of $\mathrm{pH}$ on enzyme inhibition by DPP for SAB and pepsin were

Table I. EFFEcts of SOME DIAZO-COMPOUNDS ON Activities of Three ACID Proteases

The enzymes were incubated with the chemicals in the presence and absence of cupric ions at $14^{\circ} \mathrm{C}$ and $\mathrm{pH} 4.8$ for $10 \mathrm{hr}$, and the residual activities were assayed. The other conditions are described in the text.

\begin{tabular}{lcrrr}
\hline & & \multicolumn{3}{c}{ Residual activity (relative value) } \\
\cline { 3 - 5 } Chemicals & $\mathrm{Cu}^{2+}$ & SAB & Rhizopuspepsin & Pepsin \\
\hline None & - & 100 & 100 & 100 \\
None & + & 96 & 93 & 98 \\
DAN & - & 94 & 92 & 92 \\
DAN & + & 91 & 0 & 0 \\
ZPDM & - & 92 & 94 & 95 \\
ZPDM & + & 91 & 0 & 0 \\
DPP & - & 93 & 95 & 96 \\
DPP & + & 2 & 0 & 0 \\
\hline
\end{tabular}

DAN, diazoacetyl-DL-norleucine methylester; ZPDM, $N^{\alpha}$-benzyloxycarbonyl phenylalanyl diazomethane; DPP, 1-diazo-3-phenyl-2-propanone. shown. Inhibition by DPP for SAB was $\mathrm{pH}$ dependent, more potent at higher $\mathrm{pH}$, but pepsin was inhibited by DPP equally between $\mathrm{pH} 4$ and 5.5. Course analyses of enzyme inhibitions by DPP are illustrated in Fig. 2. Pepsin was more sensitive to DPP, and more than 10 hr's incubation at $\mathrm{pH} 4.8$ and $14^{\circ} \mathrm{C}$ was necessary for complete inhibition of SAB. The presence of $0.5 \%$ casein completely prevented the inactivation of both enzymes by DPP.

Enzymatic digestion of inactive modified enzymes and isolation of DPP-labeled peptides The DPP-modified enzymes were separated from the excess reagents by gel filtration (Fig. $3)$. By measuring absorbances of the modified enzymes at $280 \mathrm{~nm}$ and $315 \mathrm{~nm}$, the numbers of DPP molecules bound per mole of pepsin and $\mathrm{SAB}$ were calculated to be 1.1 and 1.3 residues, respectively.

The DPP-modified enzymes were digested with thermolysin as described in Materials and Methods, and the resultant peptides were separated by HPLC. The elution profiles of thermolysin-digest of the modified pepsin are shown in Fig. 4. One major peak (P1) showing

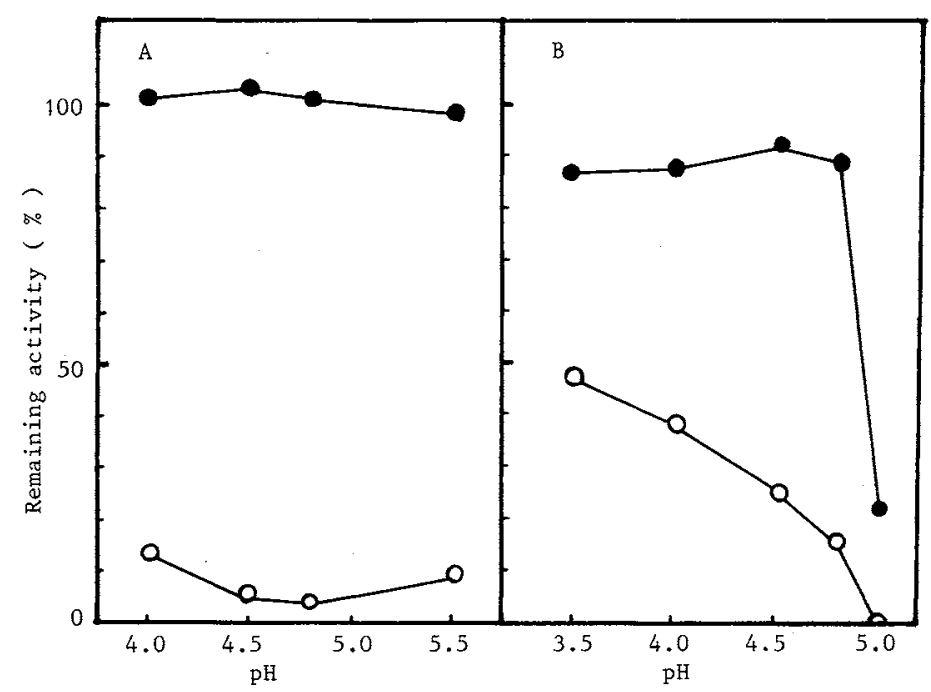

Fig. 1. Effects of $\mathrm{pH}$ on Inactivation of Pepsin and SAB by DPP.

The enzymes were incubated with DPP in the presence $(O)$ or absence $(\mathcal{O})$ of cupric ions at $14^{\circ} \mathrm{C}$ for $1 \mathrm{hr}(\mathrm{A}$ : pepsin) and $4 \mathrm{hr}(\mathrm{B}: \mathrm{SAB})$ at $\mathrm{pHs}$ indicated. The concentrations of $\mathrm{Cu}^{2+}$ and DPP were 50 -fold molar excess of the enzymes. 


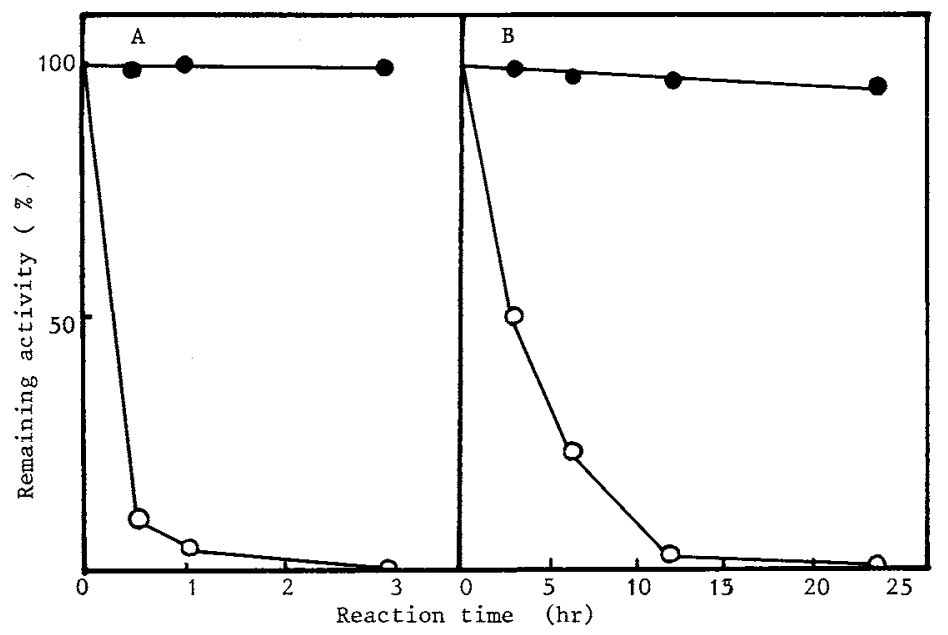

Fig. 2. Changes of Enzyme Activities upon Incubation with DPP.

Pepsin (A) and SAB (B) were incubated with DPP in the presence $(O)$ or absence $(O)$ of cupric ions at $14^{\circ} \mathrm{C}$ and $\mathrm{pH}$ 4.8. Samples of the reaction mixtures were periodically removed and the residual activities were assayed.

absorbance at $315 \mathrm{~nm}$ was observed. In case of the modified SAB, three peaks, one major (SI) and two minor (S2 and P3) peaks were detected (Fig. 5). These fractions were further purified and lyophilized.

Amino acid sequences of peptides derived from the DPP-labeled sites of enzymes

The analytical data on the DPP-labeled peptide obtained from the modified pepsin are shown in Table II-A. The amino acid sequence of P1 was Ile-Val-Asp-Thr-Gly, which coincides with the sequence of residue Nos. $213 \sim 217$ of pepsin. The Asp-215 should be labeled, as it is known to be one of the active site amino acid residues of pepsin.

The DPP-labeled site of SAB was also analyzed. The amino acid sequence of the major peak, S1, was Ala-Thr-Ser-Asp-Thr-Ser-GlySer. This sequence agrees well with that of Nos. 95 102 of SAB. Furthermore, this sequence shows significant homology to those of the active site aspartic acid residues of pepsin and other acid proteases hitherto reported. A minor peak, S2, was obtained as a mixture of two peptides and the yield was very low. In peak $S 3$, neither amino acid nor peptide was detected. This peak was tentatively assumed to

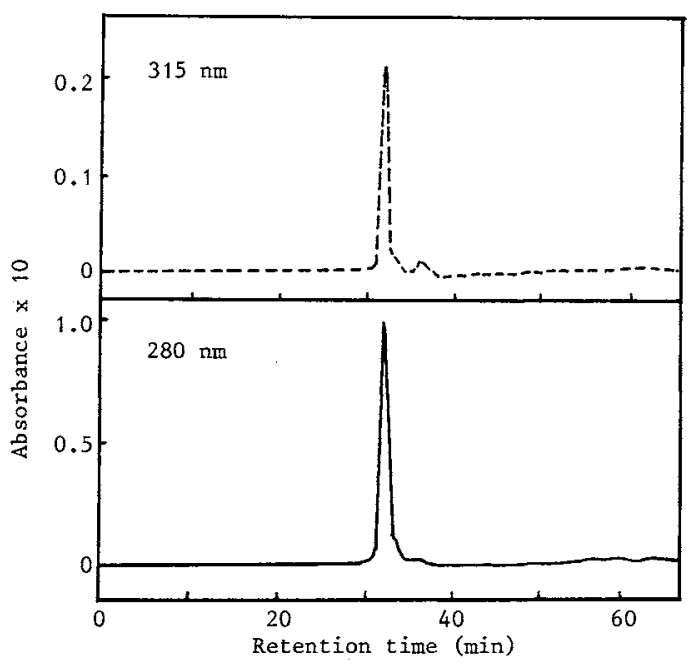

Fig. 3. Gel Filtration Pattern of DPP-Modified SAB on a TSK Gel G3000SW Column $(7.5 \times 600 \mathrm{~mm})$ in $10 \mathrm{~mm}$ Acetic Acid (pH 3.4).

About $100 \mu \mathrm{g}$ of the modified enzyme was filtered on gel at a flow rate of $0.7 \mathrm{ml} / \mathrm{min}$ at $25^{\circ} \mathrm{C}$.

be 3-phenyl-2-oxopropanol, a hydrolyzate of DPP, since alkali treatment of the DPP-labeled peptides causes the prominant increase in this peak, as shown later.

If DPP is ester-linked to the carboxyl group of acidic amino acid residues of $\mathrm{SAB}$, the modifier is expected to be released from pep- 


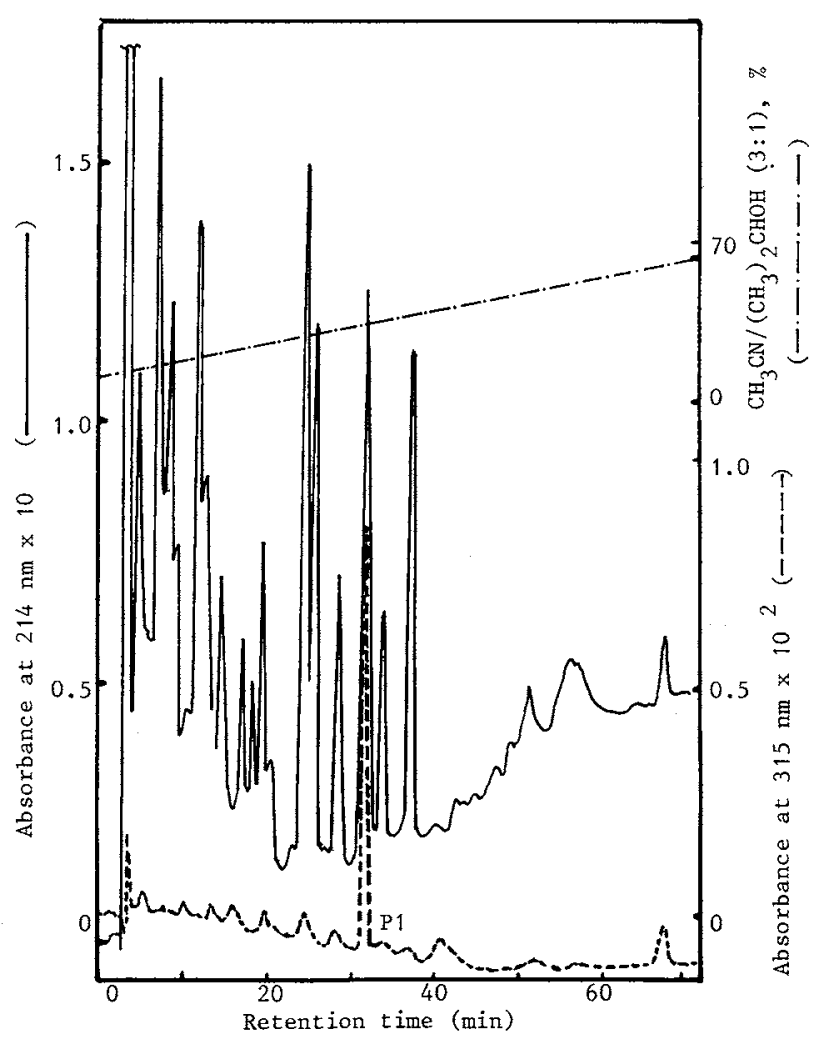

Fig. 4. HPLC Pattern of the Thermolysin-digest of DPP-Modified Pepsin.

The thermolysin-digest, $100 \mu \mathrm{l}(70 \mu \mathrm{g})$, was put on a column of TSK gel ODS-120A. An increasing linear gradient system of organic solvent (acetonitrile-2-propanol, $3: 1$ ) in $0.05 \%$ TFA was used at a flow rate of $1.0 / \mathrm{min}$ and $25^{\circ} \mathrm{C}$.

Table II. Amino Acid Sequences of Peptides Containing DPP-Reactive Residues Obtained by ThermolysinDigestion of the Modified Pepsin (A) and Scytalidium Acid Protease B (B)

\begin{tabular}{|c|c|c|c|c|}
\hline & Peptide & Amino acid sequence & $\begin{array}{l}\text { Yield } \\
(\%)\end{array}$ & $\begin{array}{l}\text { Inhibitor bound } \\
(\mathrm{mol} / \mathrm{mol})\end{array}$ \\
\hline A & $\mathrm{P} 1$ & Ile-Val-Asp-Thr-Gly & 34 & 1.1 \\
\hline \multirow[t]{3}{*}{ B } & $\mathrm{S} 1$ & Ala-Thr-Ser-Asp-Thr-Ser-Gly-Ser & 27 & 1.2 \\
\hline & $\mathrm{S} 2$ & Leu-Glu-Asn, Ile-Glu-Met-Ser & 3 & n.d. \\
\hline & S3 & No amino acid residue & 1 & 1 \\
\hline
\end{tabular}

n.d., not determined.

tides by alkali treatment, resulting in the disappearance of absorbance at $315 \mathrm{~nm}$. To examine this possibility, the $\mathrm{S} 1$ peak was incubated with $0.5 \mathrm{~N}$ hydroxylamine $(\mathrm{pH} 10.5)$ at $37^{\circ} \mathrm{C}$ for $24 \mathrm{hr}$, and HPLC patterns before and after alkali treatment were compared. Peak S1 disappeared upon this treatment, while another peak corresponding to Peak S3 increased greatly. This indicates that the dissociation of the modifier from $\mathrm{S} 1$ took place by alkali treat- 


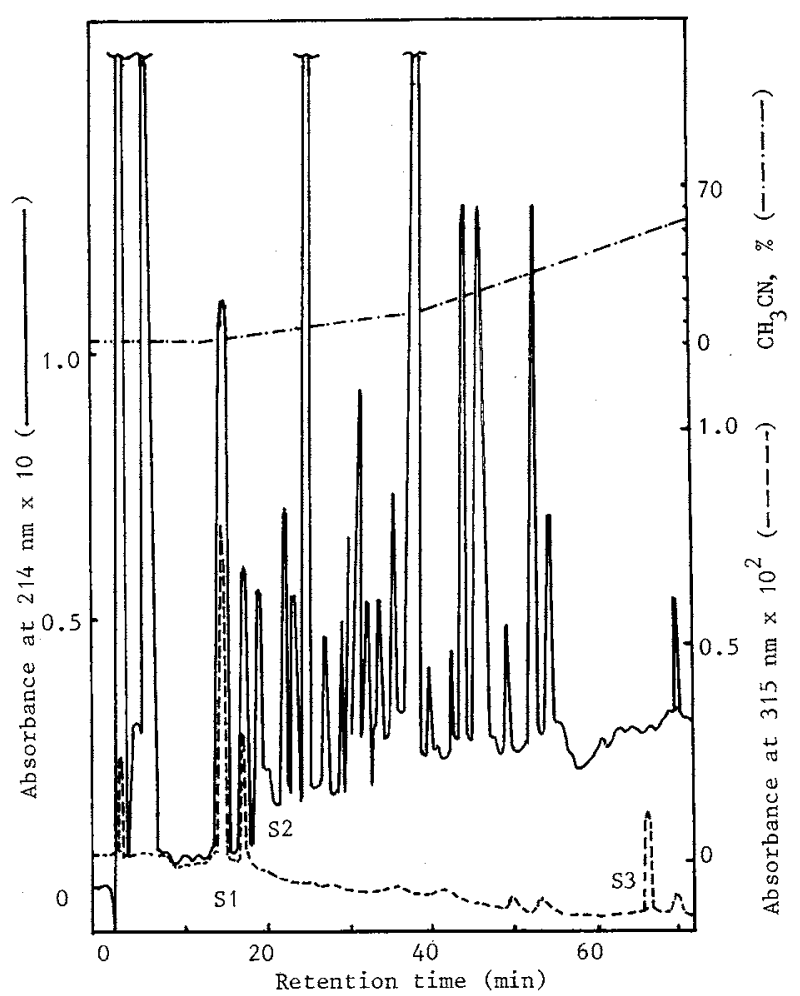

Fig. 5. Elution Profile of the Thermolysin-digest of DPP-Modified SAB.

About $50 \mu \mathrm{l}(50 \mu \mathrm{g})$ of the digest was put on the column.

The other conditions were described in the text.

ment and that the binding of the modifier to peptide is base-labile, presumably be an esterlinkage between DPP and carboxyl group of acidic amino acid in the peptide. Thus, the Asp-98 of S1 peptide seems to be the most plausible candidate for binding to DPP.

\section{Discussion}

It has been reported that sequences around the active site amino acids in acid proteases show high homology, ${ }^{1,6,19 \sim 21)}$ regardless of their origins. As shown in Fig. 6, a significant homology was observed between sequences around Asp-98 of SAB and active sites of other acid proteases.

Active site Asp-215 of pepsin is reactive to $\mathrm{DAN}^{5}$ and DPP, whereas another active site Asp-32 is esterified with EPNP. ${ }^{4,5)}$ Interestingly, the amino acid sequence around
Asp-98 of SAB, which is reactive to DPP, is more homologous to that around Asp-32 than Asp-215 of pepsin. On the contrary, the sequence around Glu-53 of SAB, which is reactive to EPNP and is possibly one of the active site amino acids of $\mathrm{SAB}$, is more homologous to that around Asp-215 than Asp-32 of pepsin. ${ }^{13,14)}$ These may be responsible for the differences in properties such as sensitivity to inhibitors and substrate specificity between $\mathrm{SAB}$ and pepsin. ${ }^{10,11)}$

Peak S2 was a mixture of peptides. We attempted to purify these peptides to homogeneity by repeating HPLC but such procedures led to the removal of the modifier from peptides as judged by absorbance at $315 \mathrm{~nm}$, and the recovery was quite low. Thus, it was very hard to elucidate the meaning for the appearance of this peak.

Taking into account the present results and 


\begin{tabular}{|c|c|}
\hline $\mathrm{SAB}$ & -Cys-GIn-Thr-Ala-Ile-Leu-Glu-Thr-Gly-Phe- \\
\hline Calf chymosin & -Cys-GIn--- - Ala-Ile-Leu-Asp-Thr-GIy-Thr- \\
\hline Porcine pepsin & 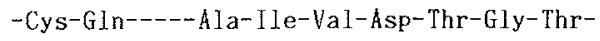 \\
\hline Penicillopepsin & ---- Ser----GIy-IIe-Ala-Asp-Thr-Gly-Thr- \\
\hline Rhizopuspepsin & -Ser-Phe-Asp-Gly-Ile-Leu-Asp-Thr-Gly-Thr- \\
\hline$S A B$ & -Thr-Ser-Asp-Thr-Ser-Gly-Ser-Ala-Thr-Leu- \\
\hline Calf chymosin & $\begin{array}{c}* \\
\text {-Leu-Phe-Asp-Thr-----Gly-Ser-Ser-Asp-Leu- }\end{array}$ \\
\hline Porcine pepsin & -Ile-Phe-Asp-Thr-----Gly-Ser-Ser-Asn-Leu- \\
\hline Penicillopepsin & -Asn-Phe-Asp-Thr----Gly-Ser-Ser-Asp-Phe- \\
\hline Rhizopuspepsin & -Asp-Phe-Asp-Thr-----Gly-Ser-Ala-Asp-Leu- \\
\hline
\end{tabular}

* Active site aspartic acid residues in acid proteases

Fig. 6. Comparison of Amino Acid Sequences Around Glu-53 and Asp-98 of Scytalidium lignicolumn Acid Protease B (SAB) with Those Around Active Site Aspartic Acid Residues of Several Acid Proteases.

the previous ones, ${ }^{13,14)}$ we conclude that two acidic amino acids, Glu-53 and Asp-98, participate in the catalytic reaction of SAB, unlike pepsin and other acid proteases, in which two aspartic acids have been reported to be involved in the enzyme reaction. Involvement of two acidic amino acid residues in the catalytic reaction of Scytalidium acid proteases has previously been suggested by Oda and Murao from kinetic and chemical modification experiments. $^{22,23)}$

Site-directed mutagenesis is now in progress in our laboratory to obtain more detailed information on the active site structure of SAB.

Acknowledgments. The authors with to express their gratitude to Professor S. Murao, Kumamoto Institute of Technology, and Dr. K. Oda, University of Osaka Prefecture, for the generous gift of a strain of Scytalidium lignicolum and valuable suggestions. Thanks are also due to Mr. N. Naotsuka and Miss R. Eguchi for their skillful assistance in these experiments.

\section{References}

1) J. Tang, "Acid Proteases," in Advances in Experimental Medicine and Biology, ed. by J. Tang, Vol. 95, Plenum Press, New York and London, 1977.

2) S. Murao and S. Satoi, Agric. Biol. Chem., 34, 1265 (1970).

3) T. G. Rajagopalan, W. H. Stein and S. Moore, J. Biol. Chem., 241, 4295 (1966)

4) J. Tang, J. Biol. Chem., 246, 4510 (1971).
5) K. C. S. Chen and J. Tang, J. Biol. Chem., 247, 2566 (1972)

6) B. Foltman and V. B. Pederson, "Acid Proteases," in Advances in Experimental Medicine and Biology, ed. by J. Tang, Vol. 95, Plenum Press, New York and London, 1977, pp. 2 22 .

7) I-N. Hsu, L. T. J. Delbaere, M. N. G. James and T. Hofmann, "Acid Proteases," in Advances in Experimental Medicine and Biology, ed by J. Tang, Vol. 95, Plenum Press, New York and London, 1977, pp. $61 \sim 81$.

8) S. Nakamura and K. Takahashi, J. Biochem., 84, 1593 (1978).

9) S. Murao, K. Oda and Y. Matsushita, Agric. Biol. Chem., 36, 1647 (1972).

10) K. Oda and S. Murao, Agric. Biol. Chem., 38, 2435 (1974).

11) K. Oda, S. Murao and K. Morihara, Agric. Biol. Chem., 39, 477 (1975).

12) T. Maita, S. Nagata, G. Matsuda, S. Maruta, K. Oda, S. Murao and D. Tsuru, J. Biochem., 95, 465 (1984).

13) D. Tsuru, S. Shimada, S. Maruta, T. Yoshimoto, K. Oda, S. Murao, T. Miyata and S. Iwanaga, $J$. Biochem., 99, 1537 (1986).

14) D. Tsuru, "Peptides and Proteases: Recent Advances" in Advances in the Biosciences, 65, 257 (1987).

15) J. Fukumoto, D. Tsuru and T. Yamamoto, Agric. Biol. Chem., 31, 710 (1966).

16) E. B. Ong and G. E. Perlmann, Nature, 215, 1493 (1967).

17) P. A. Plattner and H. Heusser, Helv. Chem. Acta, 28, 1044 (1945).

18) R. Kobayashi and G. E. Tarr, Tanpakushitsu, Kakusan and Kouso (in Japanese), 31, 991 (1986).

19) I-N. Hsu, L. T. J. Delbaere, M. N. G. James and T. Hofmann, Nature, 266, 140 (1977). 
20) R. Delaney, R. N. S. Wong, G. Meng, N. Wu and J. Tang, J. Biol. Chem., 262, 1461 (1987).

21) K. Takahashi, J. Biol. Chem., 262, 1468 (1987).

22) K. Oda and S. Murao, Agric. Biol. Chem., 50, 659
(1986).

23) K. Oda and S. Murao, Agric. Biol. Chem., 50, 1995 (1986). 